\title{
Penilaian Atribut Usabilitas oleh Gamer First Person Shooter (FPS) Indonesia
}

\author{
Paulina K. Ariningsih ${ }^{1}$, Yun P. Mulyani ${ }^{2}$, Kristianto A. Nugroho ${ }^{3}$, Chandra S. Rahardjo ${ }^{4}$ \\ ${ }^{1)}$ Fakultas Teknologi Industri, Jurusan Teknik Industri, Universitas Katolik Parahyangan \\ Jl. Ciumbuleuit 94, Bandung 40141 \\ Email: paulina.ariningsih@unpar.ac.id \\ 2) Fakultas Teknik, Jurusan Teknik Mesin dan Industri, Universitas Gadjah Mada \\ Jl. Grafika no 2, Kampus UGM, Yogyakarta, 55281 \\ Email: yun.prihantina.m@gmail.com \\ 3) Fakultas Teknologi Industri, Program Studi Industri, Universitas Atmajaya Yogyakarta \\ Kampus II, Gedung Bonaventura, Jl. Babarsari 43 Yogyakarta 55281, \\ Email: kristanto_agung@mail.uajy.ac.id \\ ${ }^{4)}$ Departemen Survelians Sistem Keuangan Bank Indonesia \\ Jl. M.H Thamrin no 2, Jakarta Pusat \\ Email: chandra_sr@bi.go.id
}

\begin{abstract}
Computer games, especially First Person Shooter (FPS) have become one of the fastest growing and most economically sucessful software in Indonesia. Given the potential economic benefits of the FPS games, it is important to design its user interface as usable as possible to win the market. In accordance, it is crucial to find out what user interface factors should be considered in designing an FPS game. These factors can be used as a designing guide for game developers in Indonesia. The purpose of this paper is to discover the main user interface factors that should be considered in designing an FPS game especially from usability point of view and to suggest improvement of the user interface in current FPS game.

Fourty (40) usabilty attributes from literature review are qualitatively grouped into 5 factors. Those factors are: Basic FPS Feature (BFF), Basic Game Feature (BGF), Display \& Sounds (D\&S), Help \& Hints $(\mathrm{H} \& \mathrm{H})$, and Enjoyment $(E)$. Usability testing on the factors is conducted in three different groups of players: Novice, Experienced, and Expert. Mann-Withney Test are conducted to understand performance difference for each group. The result shows that BGF and $\mathrm{H} \& \mathrm{H}$ are not significantly difference for all groups. While for BFF, the novice group tend to have different preference rather than other groups since there is not enough time duration given on novice users accessing the FPS feature. For D\&S, expert tend to have different preference rather than other groups. Some future research potentials are also proposed in this paper.
\end{abstract}

\section{Abstrak}

Permainan elektronik dalam komputer, terutama yang bergenre First Person Shooter (FPS) telah menjadi salah satu perangkat lunak yang paling cepat berkembang dan secara ekonomis paling sukses di Indonesia. Mengingat potensi manfaat ekonomi permainan FPS, maka penting untuk merancang user interface sebaik mungkin untuk memenangkan pasar. Maka, sangat penting untuk mengetahui faktor antarmuka apa yang harus dipertimbangkan dalam merancang sebuah game FPS. Faktor-faktor ini dapat digunakan sebagai panduan merancang untuk pengembang game di Indonesia. Tujuan dari makalah ini adalah untuk menemukan faktor antarmuka utama yang harus dipertimbangkan dalam merancang sebuah game FPS terutama dari sudut pandang usabilitas dan untuk menyarankan perbaikan user interface dalam game FPS saat ini.

Empat puluh (40) usabilty atribut dari kajian literatur secara kualitatif dikelompokkan menjadi 5 faktor. Faktor-faktor tersebut adalah: Fitur Dasar FPS (BFF), Fitur Permainan Dasar (BGF), Tampilan \& Suara (D\&S), Bantuan \& Petunjuk $(\mathrm{H} \& \mathrm{H})$, dan Kesenangan (E). Pengujian usabilitas pada faktorfaktor dilakukan kepada tiga kelompok pemain yang berbeda: Pemula, Berpengalaman, dan Ahli. Uji Mann-Whitney dilakukan untuk memahami perbedaan kinerja untuk masing-masing kelompok. Hasil pengujian menunjukkan bahwa BGF dan H\&H tidak signifikan berbeda bagi semua kelompok. Sedangkan untuk BFF, kelompok pemula cenderung memiliki preferensi yang berbeda daripada kelompok lain karena tidak ada durasi waktu yang cukup diberikan pada pengguna pemula mengakses fitur FPS. Untuk D\&S, kelompok ahli cenderung memiliki preferensi yang berbeda daripada kelompok lain. Beberapa saran penelitian masa depan juga diusulkan dalam makalah ini.

Kata kunci: Usabilitas, Game, User Interface, Antarmuka 


\section{Pendahuluan}

Permainan (game) komputer telah menjadi salah satu jenis perangkat lunak yang paling cepat berkembang dan secara ekonomis paling sukses (Zaphiris dan Ang, 2007). Entertainment Software Association melaporkan bahwa pendapatan komputer dan video game pada 2015 mencapai 111,1 miliar dolar AS di negara itu, meningkat hampir 700\% dari pendapatan tahun 2011 (ESA, 2012; ESA, 2016). Keberhasilan ini karena kemampuan untuk menarik pemain game (gamer).

Dalam menarik perhatian gamer, game designer harus mempertimbangkan beberapa faktor. Graham et. al (2007) menyatakan enam faktor yang harus diperhatikan dalam perancangan game yaitu: mempermudah pemulihan ketika terjadi kesalahan, meminimumkan hafalan, mengoptimumkan operasi, menghindari perubahan modus permainan, tidak mengejutkan pengguna, serta memberikan bimbingan dan umpan balik. Namun, detilnya akan ini tergantung pada jenis permainan yang dimainkan (Dickey, 2005).

Menurut survei yang dilakukan di rumah tangga di Amerika Serikat, permainan komputer memiliki platform pangsa pasar 1,7 kali lebih besar dari platform permainan mobile, (ESA, 2012). Ada berbagai jenis game komputer, salah satunya adalah First Person Shooter (FPS). FPS adalah jenis permainan yang membuat pemain tampaknya menembak sudut pandang orang pertama di dunia maya. Game di FPS berfokus pada menyelesaikan misi, upgrade senjata dan tindakan menembak (Sibero, 2009). Jenis game ini memerlukan teknologi perangkat keras modern untuk menampilkan virtual reality dengan ketelitian grafis yang tinggi. Keterhubungan permainan dengan jaringan aplikasi jaringan area lokal (LAN) dan internet membuat game ini bisa dimainkan secara multiplayer dengan gamer lain di seluruh dunia. Cepat gerakan pemain dan elemen visual 3D membuat permainan ini lebih menarik. Umumnya permainan ini dilakukan dalam tim. Bahkan FPS menjadi salah satu jenis eSport yang sering dimainkan dan dikompetisikan menurut International eSport Federation (ie-sf.com). FPS merupakan salah satu permainan populer di Indonesia (Mla, 2012).
Di tahun 2012 ada sebelas perusahaan pengembang game di Indonesia (Prestiliano, 2012). Sementara, di tahun 2015, diperkirakan 90 perusahaan game developer ada di Indonesia (Ardisasmita, 2015). Mereka telah memproduksi game yang dijual secara komersial, meskipun lebih banyak yang memproduksi permainan platform mobile atau aplikasi android. Hal ini menunjukkan bahwa sebenarnya potensi platform game komputer berjenis FPS di Indonesia sangat menjanjikan untuk berkembang.

Lenz dan Fox (2008) mengkaji elemen desain yang harus diprioritaskan dalam desain user interface (UI) sebuah game FPS yaitu indikator amunisi, radar dan kesehatan yang disebut sebagai tiga elemen desain utama. Ak (2012) melakukan penelitian untuk mengidentifikasi kualitas dari setiap permainan komputer berjenis edukasi dalam tiga kategori utama yaitu kesenangan, belajar dan usabilitas. Pratama dan Rahman (2012) membuat game edukasi tentang gunung berapi dan juga melakukan analisis usabilitas dengan aspek yang digunakan dalam pengujian berdasarkan Nielsen's Ten Heuristic. Metode tersebut adalah metode analisis tugas dimana peserta tes diminta untuk bermain game dan kemudian ketika peserta tes selesai bermain mereka diminta untuk mengisi kuesioner (Raaen dan Gronli, 2014).

Dickey (2005) menyelidiki cara membuat desain instruksional dengan melibatkan pengguna untuk meningkatkan kemampuan pembelajaran pemain dalam permainan elektronik populer. Fagerholt dan Lorentzon (2009) menentukan faktor UI yang penting lewat uji usabilitas dalam FPS dan menghasilkan 3 prinsip dasar, yaitu: UI dipengaruhi oleh cerita dunia virtual yang dimainkan dalam permainan, pemain perlu ditransfer ke dalam dunia virtual menjadi agen, dan UI akan lebih kuat dengan adanya avatar.

Yoon et al. (2010) merancang perangkat UI dan UX yang dapat dipakai (seperti helm, kaca mata, sarung tangan) untuk meningkatkan pengalaman virtual reality dalam memainkan FPS. Almeida et al. (2012) menganalisis skenario tingkat kesulitan video game. Sementara, Yannakakis dan Hallam (2007) serta (Fu et al., 2009) analisis tingkat kesenangan dalam permainan komputer. Kim et al. (2007) analisis tentang sensitivitas dual 
air mouse di FPS. Claypool dan Claypool (2009) penelitian tentang efek resolusi dalam bermain FPS. Sementara, Kim (2015) membuat kajian literatur untuk menggolongkan model evaluasi dan analisis usabilitas dalam permainan komputer.

Penelitian ini mengacu pada penelitian Pratama dan Rahman (2012) untuk analisis usabilitas. Hanya saja dilakukan di FPS untuk menemukan faktor-faktor yang harus diperhatikan dalam merancang sebuah game FPS. Selain menemukan faktor, penelitian juga menganalisis perbedaan tingkat usabilitas dari kelompok yang berbeda. Penelitian tersebut belum dipelajari sebelumnya.

\section{Metode Penelitian}

Penelitian ini dibagi menjadi 2 bagian yaitu pembangunan faktor usabilitas dan pengujian usabilitas terhadap faktor yang ditemukan. Pembangunan faktor usabilitas diperlukan untuk mengelompokkan atribut usabilitas yang nantinya akan diujikan. Hasil pengujian usabilitas digunakan untuk membangun usulan pembangunan game. Penelitian ini tidak merancang detail UI usulan, namun hanya sampai pada tahap analisis faktor yang perlu diperbaiki.

Penentuan faktor usabilitas dilakukan dengan kajian literatur terhadap 15 artikel dengan penggolongan secara kualitatif. Artikel yang dipilih berada dalam rentang waktu terbit antara 2007-2014 memiliki ruang lingkup pembahasan usabitas, user interaction permainan komputer. Penggolongan atribut secara kualitatif dilakukan dengan mengambil kata kunci dari masing - masing kelompok dan mengelompokkannya dengan diagram afinitas.

Pengujian usabilitas dilakukan terhadap dua judul permainan FPS, yaitu: Call of Duty Modern Warfare 2 dan Counter Strike Condition Zero. Call of Duty Modern Warfare 2 adalah sekuel dari waralaba Call of Duty yaitu salah satu game FPS paling populer di seluruh dunia untuk pengalaman gaming yang menarik, alur cerita yang menarik dan dukungan grafis yang baik. Sementara itu, Counter Strike Condition Zero merupakan sekuel dari seri Counter Strike yang cukup populer di seluruh dunia terutama karena kemudahan untuk bermain di multiplayer (melalui kabel LAN atau online) dan angka server multiplayer besar, misi yang mudah diikuti dan spesifikasi komputer yang dibutuhkan untuk memainkan game ini tidak terlalu tinggi. Metode kontrol pada kedua game ini menggunakan kombinasi keyboard dan mouse. Kondisi lingkungan penelitian dibuat mirip dengan game center, di mana kondisi kamar dan kebisingan dipilih yang menyerupai game center pada umumnya.

Peralatan yang digunakan untuk penelitian ini adalah laptop Acer Aspire 4752G dengan Intel i3-2350M (2,3 GHz, 3 MB L3 Cache), 2 GB DDR 3 RAM, Nvidia Ge-Force 610M 1 GB dan tetikus. Pengaturan modus pertandingan yang digunakan adalah secara default, hanya penyesuaian dibuat untuk tampilan visual berdasarkan kemampuan maksimal laptop.

Jumlah responden ditentukan berdasarkan economic usability test (Krug, 2006). Responden penelitian adalah mahasiswa 18 37 tahun (rata-rata: berusia 22,1 tahun) dengan metode purposive sampling (Sekaran, 2000). Rentang usia sudah sesuai dengan kategori usia permainan yaitu $E$ atau di atas 18 tahun. Jenis kelamin responden tidak diperhatikan. Detil profil dari subyek tes adalah sebagai per ditampilkan pada Tabel 1.

Tabel 1. Komposisi profil responden uji usabilitas

\begin{tabular}{|c|c|c|c|}
\hline & Ahli & $\begin{array}{c}\text { Berpe- } \\
\text { ngalaman }\end{array}$ & Pemula \\
\hline $\begin{array}{c}\text { Jumlah sampel } \\
\text { (orang) }\end{array}$ & 5 & 5 & 5 \\
\hline $\begin{array}{c}\text { Rerata umur } \\
\text { (tahun) }\end{array}$ & 20.8 & 22 & 25.5 \\
\hline $\begin{array}{c}\text { Rerata waktu } \\
\text { penggunaan } \\
\text { internet dan } \\
\text { komputer per } \\
\text { minggu (jam) }\end{array}$ & 47 & 41.25 & 48.25 \\
\hline $\begin{array}{c}\text { Rerata waktu } \\
\text { bermain game } \\
\text { komputer per } \\
\text { minggu (jam) }\end{array}$ & 19.6 & 17.33 & 6.4 \\
\hline
\end{tabular}

Responden dibagi menjadi tiga kategori. berdasar pada pengalaman bermain: pemula, berpengalaman, dan ahli. Pemula adalah tingkat ketika responden belum atau satu kali pernah bermain game FPS. Berpengalaman adalah responden yang pernah memainkan game FPS dan cukup akrab tetapi tidak pernah menyelesaikan misi permainan. Sementara tingkat ahli adalah responden yang terbiasa dan akrab dengan permainan dan telah menyelesaikan misi dalam permainan hingga tuntas. Penyaringan subyek ke kategori tertentu dilakukan dengan wawancara singkat dan mengisi formulir yang disediakan. 
Responden diperbolehkan untuk memilih salah satu dari dua pertandingan yang tersedia yang kurang disukai. Dengan demikian meskipun responden dianggap sebagai ahli, mereka akan tampil tidak sesuai kegiatan yang biasa mereka. Metode ini digunakan untuk menghindari efek negatif dari kebiasaan sampel selama pengujian usabilitas.

Tugas yang diberikan selama pengujian adalah: membuat akun, mengakses peta, mengganti senjata, mengisi senjata, melompat, berjalan, berlari, berjongkok dan menembak. Ketika reponden penelitian mengalami kesulitan menyelesaikan tugas, peneliti akan menunggu sampai responden dapat memecahkan atau menyerah tidak dapat melanjutkan. Setelah semua tugas selesai, responden diberi waktu lima menit untuk bermain game berdasarkan misi game asli. Setelah lima menit, responden diminta untuk mengisi kuesioner usabilitas permainan berdasarkan persepsi mereka. Total durasi uji adalah sekitar 15 - 20 menit.

Data diambil lewat kuesioner usabilitas diisi menggunakan skala likert dengan skor 1 untuk paling tidak usable dan skor 5 untuk paling usable dari setiap task yang dilakukan. Data dari hasil kuesioner diolah menggunakan Uji Mann-Wihtney untuk mengetahui perbedaan preferensi atribut usabilitas antara ketiga kelompok reponden. Uji tersebut dipilih karena data merupakan data non-parametrik, sesuai dengan yang direkomendasikan oleh Black (2010). Nilai a yang digunakan adalah 0,05, dengan hipotesis:

Ho : Nilai median tidak berbeda

$\mathrm{Ha}$ : Nilai median terdapat perbedaan

Ho akan ditolak jika nilai $p$-value $>\alpha$.

\section{Hasil dan Pembahasan}

Dalam bab ini dipaparkan hasil dan pembahasan analisis.

\section{Penentuan Faktor Usabilitas}

Dari literatur yang telah disebutkan dalam bab Metodologi Penelitian, didapatkan 40 atribut usabilitas. Atribut dikelompokkan ke dalam 5 faktor berdasarkan pada relevansi kata kunci antara atribut. Faktor tersebut adalah: Fitur FPS Basic (BFF), Fitur Game Basic (BGF), Tampilan \& Suara (D\&S), Bantuan \& Petunjuk $(\mathrm{H} \& \mathrm{H})$ dan Kesenangan (E). Tabel hasil afinitas atribut seperti tabel 2. Detil penggolongan terdapat pada lampiran A.
Fitur FPS dasar terkait dengan semua fitur yang mungkin spesifik dengan karakteristik game bergenre FPS saja, sedangkan Fitur Game dasar terkait dengan fitur-fitur umum bahwa permainan harus mencapai. Tampilan \& Sound hanyalah terkait dengan stimulasi visual dan audio yang diwujudkan pada sistem antarmuka. Help \& Petunjuk adalah menu tambahan yang bertindak sebagai rangsangan pada sistem antarmuka yang mudah pengguna mencapai tujuan pengguna dengan mengakses itu. Kesenangan adalah semua faktor yang berhubungan dengan persepsi pengguna kepuasan setelah menggunakan sistem.

Tabel 2. Tabel hasil diagram afinitas atribut

\begin{tabular}{|l|l|}
\hline Faktor & \multicolumn{1}{|c|}{ Atribut } \\
\hline BFF & Kontrol menembak; \\
& Kontrol ganti amunisi; \\
& Kontrol melompat; \\
& lkon mulai misi; \\
& Kontrol berlari; \\
& Kontrol ganti senjata; \\
& Kontrol berjongkok; \\
& Indikator bidikan; \\
& Indikator misi; \\
& Indikator peta; \\
Sensitivitas tetikus
\end{tabular}

\section{Preferensi Pengguna}

Masing-masing kelompok memiliki respon yang unik terhadap tiap faktor seperti pada tabel 3. 
Terhadap data tersebut, kemudian dilakukan Uji Mann-Withney dengan hasil seperti pada tabel 4 yang menunjukkan perbedaan preferensi pengguna untuk setiap faktor usabilitas.

Secara umum, semua jenis pengguna memiliki perbedaan statistik tidak signifikan dari preferensi untuk BGF dan $\mathrm{H} \& \mathrm{H}$ dengan $p$ value lebih besar dari 0,05 dan tingkat kepercayaan $95 \%$. Hal ini menunjukkan bahwa pengguna melihat dua fitur dalam cara yang sama karena fitur tersebut umum untuk permainan komputer yang pernah dimainkan responden sehingga mereka memiliki preferensi yang tidak signifikan berbeda.

Tabel 3. Rerata faktor usabilitas

\begin{tabular}{|c|l|c|c|c|}
\hline \multirow{2}{*}{ No. } & \multirow{2}{*}{ Faktor } & \multicolumn{3}{|c|}{ Rerata } \\
\cline { 3 - 5 } & & Ahli & $\begin{array}{c}\text { Berpe- } \\
\text { ngalaman }\end{array}$ & Pemula \\
\hline 1. & BFF & 4.38 & 4.35 & 4.00 \\
\hline 2. & BGF & 4.04 & 3.90 & 4.00 \\
\hline 3. & D\&S & 2.96 & 3.62 & 3.00 \\
\hline 4. & H\&H & 3.41 & 3.31 & 4.00 \\
\hline 5. & E & 3.40 & 4.07 & 2.80 \\
\hline
\end{tabular}

Tabel 4. Hasil uji Mann-Withney

\begin{tabular}{|c|c|c|c|c|c|c|}
\hline \multirow[t]{2}{*}{$\begin{array}{l}\text { Fak- } \\
\text { tor }\end{array}$} & \multicolumn{2}{|c|}{$\begin{array}{c}\text { Ahli \& Ber- } \\
\text { pengala- } \\
\text { man }\end{array}$} & \multicolumn{2}{|c|}{$\begin{array}{c}\text { Ahli \& } \\
\text { Pemula }\end{array}$} & \multicolumn{2}{|c|}{$\begin{array}{c}\text { Berpen- } \\
\text { galaman \& } \\
\text { Pemula }\end{array}$} \\
\hline & $\mathbf{Z}$ & Sig. & $\mathbf{Z}$ & Sig. & $\mathbf{Z}$ & Sig \\
\hline \multirow{2}{*}{ BFF } & -1.97 & 0.10 & -3.81 & 0.00 & -2.99 & 0.03 \\
\hline & \multicolumn{6}{|c|}{ Pemula punya preferensi berbeda } \\
\hline \multirow{2}{*}{ BGF } & -0.11 & 0.99 & -1.68 & 0.09 & -1.44 & 0.49 \\
\hline & \multicolumn{6}{|c|}{ Tidak ada perbedaan preferensi } \\
\hline \multirow{2}{*}{ D\&S } & -2.30 & 0.02 & -2.05 & 0.04 & -0.13 & 0.99 \\
\hline & \multicolumn{6}{|c|}{ Ahli punya preferensi berbeda } \\
\hline \multirow{2}{*}{$\mathrm{H} \& \mathrm{H}$} & -0.30 & 0.98 & -0.44 & 0.66 & -0.19 & 0.85 \\
\hline & \multicolumn{6}{|c|}{ Tidak ada perbedaan preferensi } \\
\hline \multirow{2}{*}{$\mathrm{E}$} & -2.15 & 0.03 & -1.30 & 0.19 & -2.35 & 0.02 \\
\hline & \multicolumn{6}{|c|}{ Ahli dan Pemula punya preferensi sama } \\
\hline
\end{tabular}

Tabel 5. menunjukkan bahwa pengguna Ahli memiliki harapan tertinggi pada faktor D\&S karena Ahli membutuhkan fitur penunjang permainan yang lebih maju/ advance sehingga memiliki preferensi terendah $(2,96)$ di antara pengguna lainnya.

Di samping itu, Ahli, memiliki preferensi yang sama dengan Pemula untuk faktor $E$ 100 dengan nilai yang rendah (masing-masing 3.40 dan 2.80). Hal ini mungkin terjadi karena dalam kondisi pengujian, Ahli cenderung untuk membandingkan edisi permainan yang digunakan dalam tes dengan permainan yang biasa dimainkan pada keseharian mereka.

Sementara itu, Pemula tidak memiliki pengalaman dalam permainan FPS sehingga mereka tidak bisa menikmati kecuali mereka tahu bagaimana permainan bekerja. Nampaknya, waktu pengujian selama 15-20 menit tidak cukup untuk dijadikan sebagai percobaan / trial pemasaran. Ketidaktahuan Pemula diutamakan pada pada fitur dasar, FPS seperti yang ditunjukkan pada hasil uji bahwa preferensi fitur dasar FPS Pemula secara signifikan berbeda dari pengguna lain dan memiliki nilai terendah antara lain $(4,00)$.

Tabel 5. Rangking atribut untuk faktor umum

\begin{tabular}{|l|l|l|}
\hline \multicolumn{2}{|c|}{$\begin{array}{c}\text { Rang- } \\
\text { king }\end{array}$} & \multicolumn{1}{|c|}{ Attribut } \\
\hline \multicolumn{3}{|c|}{ raktor BGF } \\
\hline 1 & Ikon keluar & 4,53 \\
\hline 2 & Ikon lanjutkan permainan & 4,40 \\
\hline 3 & Ikon main & 4,33 \\
\hline 4 & Ikon pause & 4,20 \\
\hline 5 & Menu sign-up akun & 3,87 \\
\hline 6 & Menu pengingat tipe kontrol & 3,80 \\
\hline 7 & Menu kustomisasi kontrol & 3,73 \\
\hline 8 & Indikator nyawa & 3,47 \\
\hline 9 & Cara penyimpanan & 3,33 \\
\hline 10 & Skipping cerita & 2,93 \\
\hline \multicolumn{3}{|c|}{ Faktor H\&H } \\
\hline 1 & Bahasa tutorial & 3,60 \\
\hline 2 & Ikon petunjuk & 3,57 \\
\hline 3 & Ikon bantuan & 3,50 \\
\hline 4 & Kemudahan mengikuti tutorial & 3,47 \\
\hline 5 & Kegamblangan bantuan & 3,36 \\
\hline 6 & Kegamblangan terjemahan & 3,27 \\
\hline 7 & Kegamblangan petunjuk & 3,13 \\
\hline
\end{tabular}

\section{Perbaikan Atribut}

Proses merangking atribut setiap faktor dilakukan terlebih dahulu untuk mengetahui atribut mana yang masih perlu diperbaiki dan menentukan prioritas perbaikan. Rangking ditentukan dari besaran nilai rerata preferensi usabilitas (kinerja) atribut tersebut. Kinerja atribut yang buruk dinyatakan dengan nilai rerata kinerja yang lebih rendah dari 3,5. 
Setelah itu, perbaikan diusulkan pada atribut dengan kinerja yang buruk.

Rangking untuk BGF dan H\&H diambil dari kinerja menurut semua kelompok karena tidak ada kelompok pengguna yang berbeda signifikan. BGF dan $\mathrm{H} \& \mathrm{H}$ disebut sebagai faktor umum, dan atributnya disebut sebagai atribut umum. Dari tabel 5 terlihat tujuh atribut umum yang dapat ditingkatkan oleh pengembang game.

Rangking untuk faktor yang terdapat perbedaan preferensi diambil dari kedua kelompok yang berbeda signifikan. Misalnya: rangking untuk BFF diambil dari preferensi usabilitas kelompok rata-rata antara Ahli dan Berpengalaman serta rata-rata Pemula. Hal ini disebabkan karena Pemula memiliki preferensi yang berbeda sesuai tabel 6 . Kinerja faktor akan berbeda antara rerata Pemula dengan rerata Ahli\&Berpengalaman yaitu indikator misi, ikon lompatan, dan sensitivitas tetikus.

Tabel 6. Rangking atribut untuk faktor BFF

\begin{tabular}{|c|c|c|}
\hline Rangk & Atribut & Rerata \\
\hline \multicolumn{3}{|c|}{ Pengguna Ahli \& Berpengalaman } \\
\hline 1 & Ikon mulai misi & 4,9 \\
\hline 2 & Kontrol melompat & 4,8 \\
\hline 3 & Kontrol menembak & 4,8 \\
\hline 4 & Kontrol ganti amunisi & 4,8 \\
\hline 5 & Kontrol berlari & 4,6 \\
\hline 6 & Kontrol ganti senjata & 4,6 \\
\hline 7 & Kontrol berjongkok & 4,5 \\
\hline 8 & Indikator bidikan & 4,3 \\
\hline 9 & Indikator misi & 4,1 \\
\hline 10 & Indikator peta & 3,6 \\
\hline 11 & Sensitivitas tetikus & 3 \\
\hline \multicolumn{3}{|c|}{ Pengguna Pemula } \\
\hline 1 & Indikator peta & 4,4 \\
\hline 2 & Kontrol menembak & 4,2 \\
\hline 3 & Kontrol ganti amunisi & 4,2 \\
\hline 4 & Kontrol berlari & 4,2 \\
\hline 5 & Indikator bidikan & 4,2 \\
\hline 6 & Ikon mulai misi & 4 \\
\hline 7 & Kontrol ganti senjata & 4 \\
\hline 8 & Kontrol berjongkok & 4 \\
\hline 9 & Indikator misi & 3,2 \\
\hline 10 & Kontrol melompat & 2,8 \\
\hline 11 & Sensitivitas tetikus & 2,6 \\
\hline
\end{tabular}

Menurut Pemula terdapat tiga atribut BFF yang perlu perbaikan, sementara menurut AhliBerpengalaman, hanya terdapat satu atribut BFF yang perlu perbaikan yaitu sensitivitas tetikus. Maka perbaikan diusulkan kepada ketiga atribut tersebut.

Proses tersebut juga berlaku pada D\&S dan E. Dari tabel 7 dan tabel 8 dapat dilihat bahwa meskipun rangking kinerja atribut berbeda untuk kedua kelompok, namun terdapat atribut yang dinilai rendah untuk keseluruhan kelompok. Misalnya: pada BFF atribut sensitivitas tetikus dinilai berkinerja buruk untuk Ahli-Berpengalaman dan Pemula.

Tabel 7. Rangking atribut untuk faktor D\&S

\begin{tabular}{|l|l|l|}
\hline \multicolumn{2}{|c|}{ Rangk } & \multicolumn{2}{|c|}{ Pengguna Ahli } & Rerata \\
\hline 1 & Lagging grafis & 4 \\
\hline 2 & Kecepatan frame rate & 3,4 \\
\hline 3 & Warna & 3 \\
\hline 4 & Efek suara & 3 \\
\hline 5 & Musik latar & 3 \\
\hline 6 & Render grafis & 2,8 \\
\hline 7 & Efek cahaya & 2,6 \\
\hline 8 & Frame rate & 2,6 \\
\hline \multicolumn{3}{|c|}{ Pengguna Pemula\&Berpengalaman } \\
\hline 1 & Lagging grafis & 3,8 \\
\hline 2 & Kecepatan frame rate & 4,2 \\
\hline 3 & Efek suara & 4 \\
\hline 4 & Render grafis & 3,9 \\
\hline 5 & Warna & 3,6 \\
\hline 6 & Frame rate & 3,4 \\
\hline 7 & Indikator musuh & 3,3 \\
\hline 8 & Musik latar & 3,2 \\
\hline
\end{tabular}

Dari tabel 8 ditunjukkan bahwa untuk faktor $\mathrm{E}$ telah memiliki kinerja yang baik untuk semuanya. Hal ini memperkuat alasan kesuksesan kedua jenis permainan yang diuji.

Tabel 8. Rangking atribut untuk faktor $E$

\begin{tabular}{|l|l|l|l|}
\hline \multirow{2}{*}{$\begin{array}{l}\text { Rang } \\
\text {-king }\end{array}$} & \multicolumn{1}{|c|}{ Atribut } & \multicolumn{2}{c|}{ Rerata } \\
\cline { 3 - 4 } & $\begin{array}{c}\text { Ahli \& } \\
\text { Pemula }\end{array}$ & $\begin{array}{l}\text { Berpeng } \\
\text {-alaman }\end{array}$ \\
\hline 1 & Kepuasan & 4,4 & 4,65 \\
\hline 2 & $\begin{array}{l}\text { Keinginan } \\
\text { bermain kembali }\end{array}$ & 4,2 & 4,50 \\
\hline 3 & Tingkat kesulitan & 3,6 & 4,50 \\
\hline
\end{tabular}


Keseluruhan atribut yang berpotensi untuk dikembangkan kinerjanya dapat dilihat pada tabel 9. Dari tabel tersebut dapat terlihat bahwa kelompok pemula memiliki ekspektasi kinerja atribut yang lebih rendah karena kecilnya referensi atribut dan kurangnya pengalaman bermain. Sedangkan kelompok pengguna yang lebih sering bermain memiliki ekspektasi kinerja atribut yang lebih tinggi. Kelompok berpengalaman memiliki ekspektasi kinerja atribut yang cukup mewakili kondisi keseluruhan pengguna.

Tabel 9. Potensi Pengembangan Atribut

\begin{tabular}{|c|c|c|}
\hline No. & Atribut & Pengaruh \\
\hline 1 & Indikator nyawa & \multirow{12}{*}{$\begin{array}{l}\text { Semua } \\
\text { Pengguna }\end{array}$} \\
\hline 2 & Cara penyimpanan & \\
\hline 3 & Skipping cerita & \\
\hline 4 & $\begin{array}{l}\text { Kemudahan mengikuti } \\
\text { tutorial }\end{array}$ & \\
\hline 5 & Kegamblangan bantuan & \\
\hline 6 & Kegamblangan terjemahan & \\
\hline 7 & Kegamblangan petunjuk & \\
\hline 8 & Sensitivitas tetikus & \\
\hline 9 & Frame rate & \\
\hline 10 & Indikator musuh & \\
\hline 11 & Musik latar & \\
\hline 12 & Efek cahaya & \\
\hline 13 & Indikator misi & \multirow{2}{*}{ Pemula } \\
\hline 14 & Kontrol melompat & \\
\hline 15 & Kecepatan frame rate & \multirow{4}{*}{ Ahli } \\
\hline 16 & Warna & \\
\hline 17 & Efek suara & \\
\hline 18 & Render grafis & \\
\hline
\end{tabular}

Dilakukan wawancara lebih lanjut terhadap responden mengenai atribut yang berpotensi untuk dikembangkan. Hasil wawancara terhadap kelompok pemula terhadap atribut indikator misi dan kontrol melompat menunjukkan bahwa: letak indikator misi tidak selalu kelihatan sehingga perlu diletakkan ke bagian layar yang lebih mudah dilihat (lebih ke tengah); sementara kontrol melompat memiliki susunan tombol yang sulit diingat dalam waktu cepat, oleh karena itu perlu diubah ke yang lebih sederhana.

Hasil wawancara terhadap kelompok ahli menunjukkan tuntutan kebutuhan yang lebih tinggi terhadap efek hiburan pada permainan. Responden kelompok ini menginginkan kecepatan frame rate yang lebih tinggi, warna 102 yang lebih naturalis, efek suara yang lebih membangkitkan kesenangan, dan render grafis yang semakin kecil.

Sementara terhadap seluruh kelompok, hasil wancara menunjukkan beberapa preferensi yang sama, dan beberapa preferensi yang berbeda. Preferensi yang sama terhadap semua pengguna berada pada fitur umum, yaitu: kebutuhan akan kemudahan akan melihat indikator nyawa, kemudahan cara penyimpanan, kemudahan cara skipping cerita, tutorial yang perlu lebih dipermudah, dan pemaparan yang lebih gamblang untuk artikel: bantuan, terjemahan dan petunjuk. Preferensi berberda didapatkan untuk sensitivitas tetikus, frame rate, indikator musuh, musik layar dan efek cahaya.

Para pemula tidak memerlukan tetikus yang terlalu sensitif karena pemula tidak dapat mengendalikan tetikus yang sensitif, sedangkan semakin ahli, pemain semakin memerlukan tetikus yang sensitif. Pergantian frame rate yang terlalu cepat akan membuat pemula menjadi lebih tidak nyaman, sementara semakin ahli pemain, maka semakin memerlukan pergantian yang cepat untuk menyelesaikan misi-nya. Indikator musuh tidak diperlukan untuk pemain ahli, namun sangat diperlukan oleh pemain pemula Ketiadaan indikator musuh menyulitkan pemain pemula menyelesaikan misi sehingga dalam waktu tertentu dapat menyebabkan frustasi karena permainan dinilai terlalu sulit. Musik layar dan efek cahaya memiliki kecenderungan preferensi yang mirip yaitu para pemula tidak memerlukan musik layar dan efek cahaya yang tinggi karena mereka perlu berkonsentrasi pada adaptasi permainan. Di pihak lain, semakin ahli seorang pemain, akan semakin memerlukan musik layar untuk meningkatkan faktor hiburan.

Perbedaan karakteristik pengguna menunjukkan bahwa game developer dapat melakukan kustomisasi pembaharuan fitur atribut tidak pada saat yang bersamaan, melainkan dapat memberikan keleluasaan pada pengguna untuk melakukan kustomisasi pembaharuan fitur atribut sesuai dengan level yang telah ditamatkan oleh pengguna. Hal ini memberikan solusi pada keekonomisan dan jumlah kebutuhan data simpan permainan maupun spesifikasi komputer untuk memainkan permainan tersebut. 


\section{Kesimpulan dan Saran}

Dalam penelitian ini, lima faktor usabilitas utama dalam mengembangkan FPS game telah dibangun sebagai dasar, meliputi: Fitur FPS Basic, Fitur Game Basic, Tampilan \& Suara, Bantuan \& Petunjuk, dan Kesenangan. Karena permainan yang digunakan dalam tes ini hanya dua, studi lebih lanjut disarankan untuk mengakses hasil yang lebih representatif atribut tersebut.

Terdapat delapan belas atribut yang perlu ditingkatkan. Dari 18 atribut tersebut, 12 atribut kurang usable untuk semua kelompok pengguna, yaitu: indikator nyawa, penyimpanan, skipping cerita, tutorial permainan, bantuan, terjemahan, sensitivitas tetikus, frame rate, indikator musuh, musik dan pencahayaan; dua atribut kurang usable untuk kelompok pemula yaitu indikator misi dan ikon lompat; serta empat atribut kurang usable untuk kelompok ahli yaitu adaptasi frame rate, warna, efek suara, dan render grafis.

Disarankan untuk membuat studi lebih lanjut pada lamanya kurva pembelajaran pemain pemula untuk mendapatkan persepsi yang sama dengan pemain berpengalaman. Studi lebih lanjut tentang preferensi pemain dan perspektif berdasarkan usia disarankan untuk dilakukan untuk memahami tingkat hiburan yang cocok untuk setiap rentang usia.

Di pihak lain, tatanan visual layar dari FPS mirip dengan tatanan visual layar simulator. Maka, hasil dari penelitian ini dapat dicobakan pula pada perangkat lunak simulator.

\section{Daftar Pustaka}

Ak, O. (2012). A game scale to evaluate educational computer games. Procedia Social and Behavioral Sciences, 46, 2477 2481.

Almeida, S., Veloso, A., Mealha, Ó., Roque, L. \& Moura, A. (2012). A Video Game Level Analysis Model Proposal. International Conference on Information Visualisation. IEEE.

Ardisasmita, A. (2015). Berapa Jumlah Studio Game di Indonesia?

https://ardisaz.com/2015/09/22/berapajumlah-studio-game-di-indonesia/ [2016, 14 Oktober]

Black, K. (2010). Business Statistics for Contemporary Decision Making, $6^{\text {th }}$ edition. USA : John Wiley \& Sons, Inc.
Claypool, K. \& Claypool, M. (2009). The Effects of Resolution on Users Playing First Person Shooter Games. Proceedings of ACM/SPIE Multimedia Computing and Networking (MMCN). San Jose, California, USA.

Dickey, M. D., 2005, Engaging By Design: How Engagement Strategies in Popular Computer and Video Games Can Inform Instructional Design. InEducational Technology Research \& Development, 53, 67-83.

E. S. A. (2012). Sales, Demographic and Usage Data: Essential Facts About The Computer and Video Game Industry. www.theESA.com [2016, Oktober 14]

E. S. A. (2016). 2015 Annual Report. www.theESA.com [2016, Oktober 14]

Fagerholt, E. \& Lorentzon, M. (2009). Beyond the HUD User Interfaces for Increased Player Immersion in FPS Games. Master Thesis. CHALMERS UNIVERSITY OF TECHNOLOGY.

Fu, F.-L., Su, R.-C. \& Yu, S.-C. (2009). EGameFlow: A scale to measure learners' enjoyment of e-learning game. Computers \& Education, 52, 101-112.

Friker, H. (2012). Game User Interface Guideline: Creating a set of Usability Design Guidelines for the FPS Game UserInterface. Master Thesis: University of Huddersfiled

Graham, T. C. N., Curzon, P., Doherty, G., Palanque, P., Potter, R., Roast, C. \& Smith, S. P. (2007). Usability and Computer Games: Working Group Report. DSVIS 2006, LNCS 4323, 265-268.

Kim, Y.-B., Shim, M.-S., Song, C. G. \& Kim, Y.S. (2007). A First Person Shooter with Dual Guns Using Multiple Optical Air Mouse Devices. International Proceeding Conference on Artificial Reality and Telexistence. IEEE.

Kim, J-Y. (2015). A Study on Comparison and Analysis of Usability Evaluation Model Gameplay. Advanced Sciences and Technology Letters, Vol. 99, pp. 227-230

Krug, S. (2006). Don't make me think $2^{\text {nd }}$ edition. Berkeley: New Riders Publishing

Lenz, K. \& Fox, D. (2008). Examining the Critical User Interface Components of FirstPerson Shooter (FPS) Games. Usability News, 10. 
Mla, 2012, Game Apa yang Paling Digemari di Indonesia? , Jakarta: detikinet, [Online,diakses pada tanggal 23 Oktober 2012]

Pratama, D. \& Rahman, A. (2012). Perancangan Game Edukasi pada Bencana Erupsi gunung Berapi. TEKNIK POMITS, 1.

Prestiliano, J. (2012). Animasi \& Game Kreatif Sebagai Sebuah Peluang Usaha \& Lapangan Kerja.

Raanen, K., Gronli, T. (2014). Latency Thresholds for Usability Games: A Survey. http://ojs.bibsys.no/index.php/NIK/article/vie w/9/6 [2016, 14 Oktober]

Sekaran, U. (2000). Research Methods for Business: A Skill Building Approach, $3^{\text {rd }}$ edition. USA: John Wiley \& Sons, Inc.

Sibero, I. C. (2009). Langkah Mudah Membuat Game 3D, Yogyakarta: MediaKom.
Snow, B. (2007). Gaming Usability 101. http://www.bloomberg.com/news/articles/20 07-10-12/gaming-usability-

101 businessweek-business-news-stockmarket-and-financial-advice $[2016,14$ Oktober]

Yannakakis, G. N. \& Hallam, J. (2007). Capturing Player Enjoyment in Computer Games. Studies in Computational Intelligence (SCI), 71, 175-201.

Yoon, J.-W., Jang, S.-H. \& Cho, S.-B. (2010). Enhanced User Immersive Experience with a Virtual Reality based FPS Game Interface. IEEE Proceeding Conference on Computational Intelligence and Games.

Zaphiris, P. \& Ang, C. S. (2007). HCl Issues in Computer Games, Interacting with Computer, 19, 135-139.

Lampiran A. Tabel penggolongan atribut berdasar kata kunci

\begin{tabular}{|c|c|c|c|}
\hline No & Atribut & Kata kunci & Sumber \\
\hline 1 & Ikon mulai & BGF & $\begin{array}{l}\text { Huang and Lai (2007); Snow (2007), Kim } \\
\text { (2015) }\end{array}$ \\
\hline 2 & Kontrol menembak & BFF & $\begin{array}{l}\text { Leinz and Fox (2012); Yong et al (2010), Kim } \\
(2015)\end{array}$ \\
\hline 3 & Kontrol melompat & BFF & Almeida et al (2012), Kim (2015) \\
\hline 4 & Kontrol mengganti amunisi & BFF & Leinz and Fox (2012), Kim (2015) \\
\hline 5 & Ikon keluar & BGF & $\begin{array}{l}\text { Pratama and Rahman (2012); Huang and Lai } \\
\text { (2007); Snow (2007), Kim (2015) }\end{array}$ \\
\hline 6 & Kontrol berlari & BFF & $\begin{array}{l}\text { Yong et al (2010); Almeida et al (2012), Kim } \\
(2015)\end{array}$ \\
\hline 7 & Kontrol ganti senjata & BFF & Almeida et al (2012), Kim (2015) \\
\hline 8 & Ikon melanjutkan permainan & BGF & Snow (2007) Kim (2015) \\
\hline 9 & Ikon jongkok & BFF & Almeida et al (2012) \\
\hline 10 & Ikon bermain & BGF & $\begin{array}{l}\text { Pratama and Rahman (2012); Huang and Lai } \\
\text { (2007), Kim (2015) }\end{array}$ \\
\hline 11 & Ikon pause & BGF & $\begin{array}{l}\text { Pratama and Rahman (2012); Huang and Lai } \\
\text { (2007), Kim (2015) }\end{array}$ \\
\hline \multirow{2}{*}{12} & \multirow{2}{*}{ Indikator bidikan } & BFF & Leinz and Fox (2012) \\
\hline & & D\&S & Fagerholt (2009) \\
\hline 13 & $\begin{array}{l}\text { Kemudahan untuk pembukaan } \\
\text { akun }\end{array}$ & BGF & $\begin{array}{l}\text { Ak (2012); Pratama and Rahman (2012), Kim } \\
\text { (2015) }\end{array}$ \\
\hline 14 & Kemudahan mengingat kontrol & BGF & Snow (2007), Fricker (2012), Kim (2015) \\
\hline 15 & Kesenangan & $\mathrm{E}$ & Ak (2012), Fricker (2012) \\
\hline 16 & $\begin{array}{l}\begin{array}{l}\text { Kemudahan mengganti ikon } \\
\text { kontrol }\end{array} \\
\end{array}$ & BGF & Snow (2007), Kim (2015) \\
\hline \multirow{2}{*}{17} & \multirow{2}{*}{ Warna } & D\&S & $\begin{array}{l}\text { Leinz and Fox (2012); Fricker (2012), Kim } \\
(2015)\end{array}$ \\
\hline & & $\mathrm{H} \& \mathrm{H}$ & $\begin{array}{l}\text { Pratama and Rahman (2012); Huang and Lai } \\
\text { (2007); Fagerholt (2009) }\end{array}$ \\
\hline 18 & Keinginan memainkan kembali & $E$ & Fu et al (2008) \\
\hline 19 & Indikator misi & BGF & $\begin{array}{l}\text { Pratama and Rahman (2012); Snow (2007); } \\
\text { Fagerholt (2009) }\end{array}$ \\
\hline
\end{tabular}




\begin{tabular}{|c|c|c|c|}
\hline 20 & Frame rate & D\&S & $\begin{array}{l}\text { Pratama and Rahman (2012); Dickey (2005); } \\
\text { Fagerholt (2009); Claypool (2007), Kim (2015) }\end{array}$ \\
\hline \multirow{2}{*}{21} & \multirow{2}{*}{ Kegamblangan tutorial permainan } & BGF & $\begin{array}{l}\text { Ak (2012); Pratama and Rahman (2012); } \\
\text { Snow (2007), Kim (2015) }\end{array}$ \\
\hline & & $\mathrm{H} \& \mathrm{H}$ & Dickey (2005) \\
\hline \multirow{2}{*}{22} & \multirow{2}{*}{ Hint } & BGF & $\begin{array}{l}\text { Pratama and Rahman (2012); Snow (2007), } \\
\text { Kim (2015) }\end{array}$ \\
\hline & & $\mathrm{H} \& \mathrm{H}$ & Dickey (2005) \\
\hline 23 & Adapting for rapid frame rate & D\&S & Dickey (2005) \\
\hline 24 & Render grafis & D\&S & $\begin{array}{l}\text { Pratama and Rahman (2012); Dickey (2005); } \\
\text { Fagerholt (2009); Claypool (2007) }\end{array}$ \\
\hline \multirow{2}{*}{25} & \multirow{2}{*}{ Help button } & BGF & Ak (2012); Snow (2007), Kim (2015) \\
\hline & & $\mathrm{H} \& \mathrm{H}$ & Pratama and Rahman (2012) \\
\hline 26 & Ease to follow game tutorial & $\mathrm{H} \& \mathrm{H}$ & $\begin{array}{l}\text { Pratama and Rahman (2012); Dicke (2005), } \\
\text { Kim (2015) }\end{array}$ \\
\hline \multirow{2}{*}{27} & \multirow{2}{*}{ Health indictor } & BFF & Leinz and Fox (2012); Almeida et al (2012) \\
\hline & & D\&S & Fagerholt (2009) \\
\hline 28 & Efek cahaya & D\&S & Fagerholt (2009), Kim (2015) \\
\hline \multirow{2}{*}{29} & \multirow{2}{*}{ Help content } & BGF & Ak (2012); Snow (2007), Kim (2015) \\
\hline & & $\mathrm{H} \& \mathrm{H}$ & Dickey (2005) \\
\hline 30 & Cara menyimpan permainan & BGF & $\begin{array}{l}\text { Pratama and Rahman (2012); Snow (2007), } \\
\text { Kim (2015) }\end{array}$ \\
\hline \multirow{2}{*}{31} & \multirow{2}{*}{ Kegamblangan terjemahan } & BGF & Snow (2007) \\
\hline & & $\mathrm{H} \& \mathrm{H}$ & Dickey (2005) \\
\hline 32 & Efek suara & D\&S & $\begin{array}{l}\text { Pratama and Rahman (2012); Huang and Lai } \\
\text { (2007); Fricker (2012), Kim (2015) }\end{array}$ \\
\hline 33 & Indikator peta & BFF & Leinz and Fox (2012); Fricker (2012) \\
\hline 34 & Musik latar & D\&S & Pratama and Rahman (2012), Kim (2015) \\
\hline 35 & Tingkat kesulitan permainan & BGF & Snow (2007); Yannakis and Hallam (2007) \\
\hline 36 & Kegamblangan Petunjuk & $\mathrm{H} \& \mathrm{H}$ & Pratama and Rahman (2012), Kim (2015) \\
\hline 37 & Sensitivitas tetikus & D\&S & Kim et al, 2007 \\
\hline 38 & Skipping story & BGF & Snow (2007) \\
\hline \multirow{2}{*}{39} & \multirow{2}{*}{ Indikator musuh } & BGF & Yannakis and Hallam (2007) \\
\hline & & BFF & Almeida et al (2012) \\
\hline 40 & Lagging grafis & D\&S & Claypool (2007) \\
\hline
\end{tabular}

